\title{
ETHANOL METABOLISM AND PRODUCTION OF FREE ACETATE IN THE HUMAN LIVER
}

\author{
By FRANK LUNDQUIST, NIELS TYGSTRUP, KJELD WINKLER, KRESTEN \\ MELLEMGAARD AND SIVERT MUNCK-PETERSEN
(From the Department of Forensic Medicine, Medical Department B, Cardiologic Laboratory of Medical Department B, Rigshospitalet; and Institute of Medical Physiology, \\ University of Copenhagen, Denmark)
}

(Submitted for publication September 28, 1961 ; accepted December 28, 1961.

Lundsgaard solved the problem of identifying the organ in which the first stage of the metabolism of ethanol takes place (1). He clearly demonstrated that in cats the liver accounts for 90 per cent or more of the ethanol removed from the circulating blood. He also observed that an organic acid is produced in the perfused liver during alcohol metabolism.

The question of the pathway of ethanol metabolism, however, is still partly unsolved. Several possibilities may be considered. There is general agreement that oxidation to acetaldehyde is the first stage in the metabolic conversion of ethanol, but at least three possibilities may be envisaged for the fate of acetaldehyde. Its oxidation may lead to the formation of acetyl coenzyme A, (acetyl-CoA, a common intermediate in the breakdown of carbohydrate, amino acids, and fats) or to free acetate, or it could possibly enter into a number of condensation reactions (2). If acetylCoA were the primary product of acetaldehyde oxidation, acetoacetate (and $\beta$-hydroxybutyrate) might be formed, in addition to oxidation to carbon dioxide and water and incorporation into other substances.

Experiments in which an enzymic method was used for acetate determination have shown that the concentration of acetate in peripheral blood of human subjects increases to about 20 times the normal level when ethanol is present in the organism, whereas neither fasting nor the intake of a meal rich in fats influences the blood acetate concentration (3).

On the other hand, Forsander and Räihä (4), while confirming the presence of acetate in the blood of rats given ethanol, found a considerable increase in acetoacetate. Lundsgaard (1) found no significant increase in ketone bodies in perfused cat liver.
The present experiments were designed to ascertain to what extent free acetate is formed in the liver from ethanol in normal human subjects and to study other metabolic changes during ethanol combustion, including the influence of ethanol on the splanchnic oxygen consumption. Seligson and co-workers (5), in an abstract, have reported a somewhat similar study comprising two normal and two cirrhotic patients.

\section{METHODS}

Nine males and one female with no known hepatic or metabolic disorder were examined (Table I). They were fasted for 12 hours and premedicated with $200 \mathrm{mg}$ of phenobarbitone. A Cournand catheter was placed in one of the right hepatic veins and a polythene catheter in the femoral artery. Blood was drawn simultaneously from the two catheters into heparinized syringes.

The experiments comprised a control and an ethanol period, each lasting about 30 minutes. Twenty minutes before the control period a priming dose of $150 \mathrm{mg}$ of sulfobromophthalein (BSP) was given, and an infusion of BSP was started (at an average rate of $4.7 \mathrm{mg}$ per minute). During the control period 4 to 6 samples were taken from both catheters for the determination of BSP and 2 to 3 for the determination of acetate; in some cases 2 to 3 samples were taken for glucose, ketones, and lactate; in the middle of the period, $\mathrm{O}_{2}$ saturation, $\mathrm{O}_{2}$ tension, $\mathrm{pH}$, and $\mathrm{CO}_{2}$ tension were determined in one sample. The ethanol period was started with a single injection of 70 mmoles of ethanol, except in Subject 2 in whom the injection caused venospasm. Simultaneously, a constant infusion of 2.7 mmoles per minute of ethanol was started and continued for the rest of the experiment. During this period BSP and ethanol were determined in 5 to 8 samples; acetate and, in some cases, ketones, glucose, and lactate were determined in 4 to 6 samples; and $\mathrm{O}_{2}$ saturation, $\mathrm{O}_{2}$ tension, $\mathrm{pH}$, and $\mathrm{CO}_{2}$ tension in one sample in the middle of the period.

BSP (6), ethanol (7), acetate (8), acetoacetate, $\beta$-hydroxybutyrate (9), glucose $(10)$, and lactate (11) were determined in heparin plasma by the methods indicated. From the hematocrit values the results were calculated 
TABLE I

Experimental subjects

\begin{tabular}{rcccl}
\hline \hline No. & Age & Height & Weight & Sex \\
\hline & yrs & $c m$ & $k g$ & \\
1 & 35 & 172 & 79 & $\mathrm{M}$ \\
2 & 37 & 174 & 78 & $\mathrm{M}$ \\
3 & 22 & 172 & 62 & $\mathrm{M}$ \\
4 & 27 & 169 & 64 & $\mathrm{M}$ \\
5 & 45 & 159 & 40 & $\mathrm{~F}$ \\
6 & 56 & 161 & 38 & $\mathrm{M}$ \\
7 & 21 & 177 & 68 & $\mathrm{M}$ \\
8 & 32 & 170 & 63 & $\mathrm{M}$ \\
9 & 19 & 172 & 61 & $\mathrm{M}$ \\
10 & 18 & 180 & 63 & $\mathrm{M}$ \\
\hline
\end{tabular}

for whole blood. Hepatic blood flow was calculated as indicated by Bradley, Ingelfinger, Bradley and Curry (12). Separate experiments were made to measure the distribution of ethanol and acetate between erythrocytes and plasma. Ethanol was present in proportion to the amount of water, whereas acetate was distributed in accordance with the Donnan equilibrium, since the concentration in the water phase of the erythrocytes was approximately 90 per cent of that in the water phase of the surrounding plasma.

Oxygen saturation was determined by a reflectometer; $\mathrm{O}_{2}$ tension by a falling mercury drop electrode (13) ; $\mathrm{pH}$ and $\mathrm{pCO}_{2}$ by Astrup's method (14); and hemoglobin concentration by a spectrophotometer. The oxygen content of whole blood was calculated from the oxygen saturation and the oxygen capacity of the sample.

\section{RESULTS}

Figure 1 shows a typical experiment. It was found in all cases that the arterial blood acetate concentration reached a nearly constant level, about $0.8 \mathrm{mM}$, soon after the ethanol infusion was started. The arteriohepatic venous acetate and ethanol concentration differences showed only small variations within each experiment. In one experiment (no. 2) the arterial ethanol concentration rose steadily from 2 to $4 \mathrm{mM}$ during the experiment. The arteriohepatic venous differences for ethanol and acetate were also constant in this case.

Table II gives a summary of 10 experiments. In all cases the output of acetate from the splanchnic area was more than 50 per cent of the ethanol disappearance. The average fall in hepatic blood flow in the ethanol period is statistically significant $(p<0.05)$. The small drop in the average splanchnic oxygen consumption on the other hand is not statistically significant $(p>0.1)$. The splanchnic oxygen consumption and ethanol re- moval appeared to be correlated $(\mathrm{r}=+0.69)$, and the same was the case with acetate production and hepatic blood flow $(r=+0.73)$. These correlation coefficients are statistically significant at the 5 per cent but not at the 1 per cent level. The number of experiments is too limited to warrant an interpretation of these findings. The arteriohepatic venous difference in total ketone body concentration was found to be insignificant in all experiments except one (no. 5), where the net output of acetoacetate and $\beta$-hydroxybutyrate was 0.10 mmole in the control period and 0.18 mmole in the ethanol period.

The ratio of acetoacetate to $\beta$-hydroxybutyrate in the blood from the hepatic vein decreased significantly during the ethanol period in all experiments, as seen in Table III. The lactate concentration in arterial blood increased during the ethanol period in the three cases examined. This increase is not caused exclusively by production of lactate in the liver, as seen in a typical experiment (Table IV). In the two other experiments a small output (about 0.14 mmole per minute) from the splanchnic area was measured, while the arterial lactate concentration rose at a rate of about $0.02 \mathrm{mM}$ per minute.

The blood glucose concentrations in the hepatic venous blood showed considerable fluctuation during the experiments, rendering an assessment of

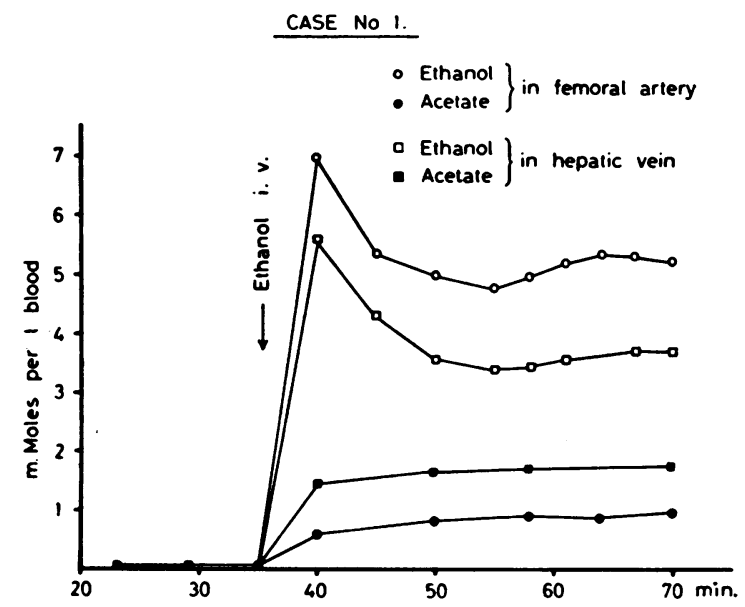

Fig. 1. Typical EXPERIMENT; PLASMa CONCENTRATIONS OF ETHANOL AND ACETATE IN THE FEMORAL ARTERY AND HEPATIC VEINS. At the time indicated by the arrow intravenous administration of ethanol was started with a single injection, followed by a constant infusion (experiment 1). 
TABLE II

Determination of ethanol consumption and acetate production in the splanchnic area of the 10 subjects *

\begin{tabular}{|c|c|c|c|c|c|c|c|c|c|c|}
\hline \multirow[b]{2}{*}{ Exp. no. } & \multirow{2}{*}{$\begin{array}{l}\text { Hepatic } \\
\text { blood flow }\end{array}$} & \multirow{2}{*}{$\begin{array}{l}\text { Splanch. } \\
\text { A-V } \\
\mathrm{O}_{2} \text { diff. }\end{array}$} & \multirow{2}{*}{$\begin{array}{l}\mathrm{O}_{2} \text { consump., } \\
\text { splanch. } \\
\text { area }\end{array}$} & \multirow{2}{*}{$\begin{array}{l}\text { Av. art. } \\
\text { plasmaa } \\
\text { acetate } \\
\text { conc. }\end{array}$} & \multirow{2}{*}{$\begin{array}{l}\text { Av. art. } \\
\text { plasma } \\
\text { ethanol } \\
\text { conc. }\end{array}$} & \multicolumn{2}{|c|}{$\begin{array}{l}\text { A-V diff. calculated, } \\
\text { whole blood }\end{array}$} & \multirow{2}{*}{$\begin{array}{l}\text { Ethanol } \\
\text { consump., } \\
\text { splanch. } \\
\text { area }\end{array}$} & \multirow{2}{*}{$\begin{array}{l}\text { Acetate } \\
\text { product., } \\
\text { splanch. } \\
\text { area }\end{array}$} & \multirow{2}{*}{$\begin{array}{c}\frac{\text { Acetate product. }}{\text { Ethanol consump. }} \\
\quad \times 100\end{array}$} \\
\hline & & & & & & Ethanol & Acetate & & & \\
\hline \multirow[b]{2}{*}{1} & $L / \min \dagger$ & $\begin{array}{l}\text { mmoles } / \\
L \dagger\end{array}$ & $\begin{array}{c}\text { mmoles } / \\
\text { mint }\end{array}$ & $m M$ & $m M$ & $m M$ & $m M$ & $\underset{\text { min }}{\operatorname{mmoles} /}$ & $\underset{\min }{\operatorname{mmoles} /}$ & $\%$ \\
\hline & $\begin{array}{l}2.14 \\
1.74\end{array}$ & $\begin{array}{l}2.06 \\
2.59\end{array}$ & $\begin{array}{l}4.37 \\
4.50\end{array}$ & & & & & & & \\
\hline \multirow[t]{2}{*}{2} & 1.36 & 2.54 & 3.48 & 0.81 & 4.70 & 1.23 & -0.70 & 2.14 & 1.21 & 56 \\
\hline & 1.23 & 2.77 & 3.40 & 0.78 & 2.59 & 1.46 & -0.80 & 1.80 & 0.99 & 55 \\
\hline 3 & $\begin{array}{l}1.95)+ \\
\text { (1.95) }\end{array}$ & $\begin{array}{l}2.00 \\
2.23\end{array}$ & $\begin{array}{l}(4.02)_{t} \\
4.33\end{array}$ & 0.78 & 1.70 & 0.91 & -0.76 & 1.78 & 1.47 & 83 \\
\hline \multirow[t]{2}{*}{4} & 1.47 & 1.56 & 2.28 & & & & & & & \\
\hline & 1.30 & 1.65 & 2.14 & 0.59 & 2.78 & 0.89 & -0.93 & 1.15 & 1.20 & 104 \\
\hline 5 & $\begin{array}{l}1.53 \\
1.47\end{array}$ & $\begin{array}{l}2.04 \\
2.46\end{array}$ & $\begin{array}{l}4.02 \\
3.61\end{array}$ & 0.95 & 7.52 & 1.56 & -0.88 & 2.29 & 1.29 & 56 \\
\hline 6 & 1.61 & 2.14 & 3.44 & & & & & & & \\
\hline \multirow{2}{*}{7} & 1.62 & $\begin{array}{l}2.46 \\
2.46\end{array}$ & $\begin{array}{l}3.98 \\
.86\end{array}$ & 0.80 & 3.28 & 0.82 & -0.84 & 1.33 & 1.35 & 101 \\
\hline & 1.31 & 1.92 & 2.50 & 0.84 & 4.67 & 0.67 & -0.61 & 0.87 & 0.80 & 92 \\
\hline 8 & $\begin{array}{l}1.77 \\
1.48\end{array}$ & $\begin{array}{l}1.47 \\
1.43\end{array}$ & $\begin{array}{l}2.59 \\
2.10\end{array}$ & 0.43 & 3.08 & 0.84 & -0.76 & 124 & 113 & 01 \\
\hline 9 & 1.46 & 2.23 & 3.26 & & & $0.0 x$ & 0.0 & 1.21 & 1.00 & 91 \\
\hline \multirow[t]{2}{*}{10} & $\begin{array}{l}1.14 \\
2.23\end{array}$ & $\begin{array}{l}2.32 \\
1.96\end{array}$ & $\begin{array}{l}2.63 \\
4.42\end{array}$ & 0.82 & 3.11 & 1.39 & -0.73 & 1.58 & 0.83 & 53 \\
\hline & 1.47 & 2.10 & 3.08 & 0.79 & 2.97 & 0.89 & -0.54 & 1.31 & 0.79 & 60 \\
\hline Average & $\begin{array}{l}1.64 \\
1.42\end{array}$ & $\begin{array}{l}2.10 \\
2.19\end{array}$ & $\begin{array}{l}3.48 \\
3.22\end{array}$ & 0.76 & 3.64 & 1.07 & -0.76 & 1.55 & 1.11 & 75 \\
\hline
\end{tabular}

* The concentrations given are average values for several samples (see Methods).

$\dagger$ The upper figures refer to the control periods.

$\ddagger$ No determination of the blood flow was made in this control period. The figure for the experimental period has been applied in the calculation of the oxygen consumption.

net splanchnic glucose balance unreliable (15). In spite of this, the splanchnic glucose output in most cases tended to decrease during the ethanol period, as illustrated in Table V. In most cases the $\mathrm{pH}$ of the hepatic venous blood was reduced during the ethanol infusion (on an average from 7.40 to 7.35), showing that acid was formed in the splanchnic area. From the $\mathrm{pH}$ and $\mathrm{pCO}_{2}$ figures.

TABLE III

Changes in the ratio acetoacetate/ $\beta$-hydroxybutyrate in blood plasma during ethanol metabolism *

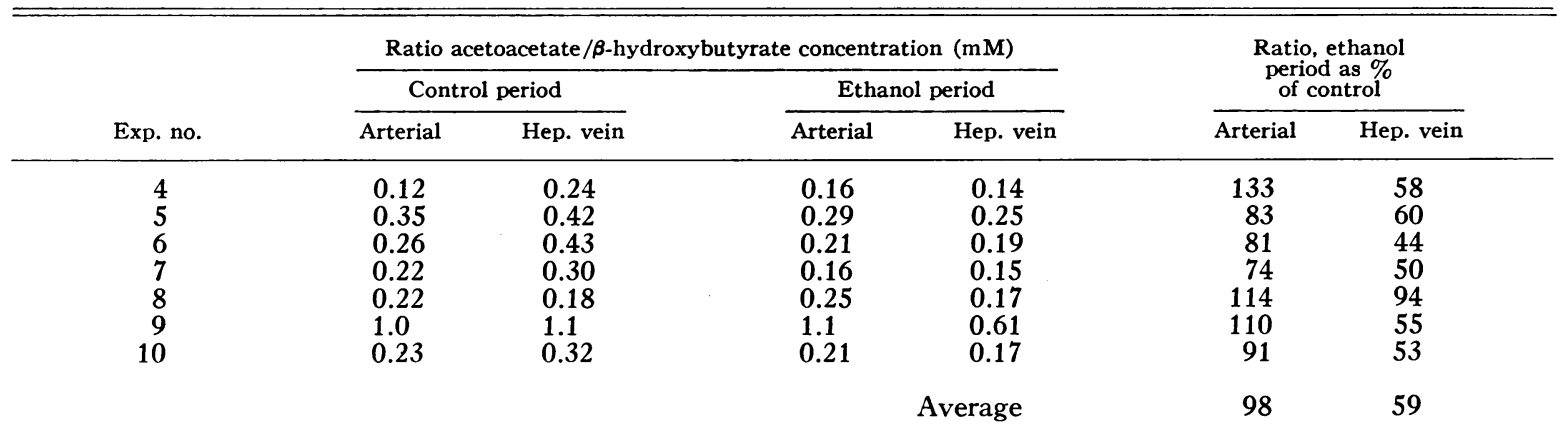

* In most experiments 2 samples in the control period and 4 to 6 samples in the ethanol period were used. The A-V difference for total ketone bodies generally did not change significantly when the ethanol infusion was started. 
TABLE IV

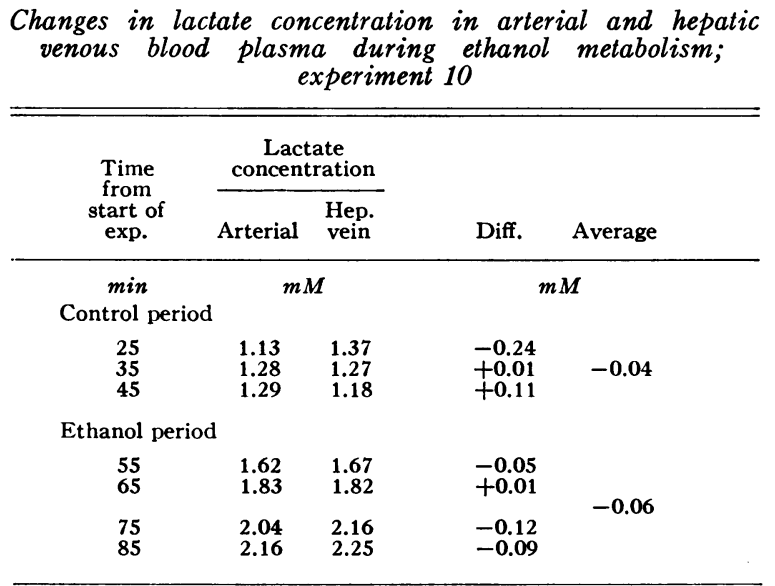

\section{INTERPRETATION AND DISCUSSION}

The previously observed increase in blood acetate (3) during ethanol metabolism does not show to what extent the ethanol that is metabolized is liberated into the blood stream as free acetate. In the present experiments, however, it is clear that a major part of the ethanol is oxidized to free acetate. Compared with most other studies on ethanol metabolism the blood ethanol concentrations employed in the present study are low. This was done partly to permit an accurate determination of the arteriohepatic venous difference and partly because it was considered desirable to study the ethanol metabolism in organisms showing no signs of intoxication. Another metabolic effect of ethanol, the inhibition of the hepatic elimination of galactose, in previous experiments was found to be fully developed at similar concentrations of ethanol (17), and it has been observed (3) that the acetate concentration in venous blood is independent of the blood ethanol concentration within wide limits-another indication in support of the widely accepted view that ethanol metabolism in man does not depend upon the concentration in the range investigated.

The question now arises: What happens to the part of the ethanol that is not recovered as acetate in the venous blood from the liver? The most obvious explanation, perhaps, is that it is oxidized to $\mathrm{CO}_{2}$ and water in the liver; but this assumption meets with considerable opposition. Forsander, Räihä and Suomalainen (18) examined the fate of $\mathrm{C}^{14}$-labeled ethanol in perfused rat liver and found that the $\mathrm{CO}_{2}$ formed contained no appreciable radioactivity. Also, experiments by Bartlett and Barnet (19) with liver slices gave evidence that only a small part of the ethanol is converted to $\mathrm{CO}_{2}$ in the liver. These findings are in agreement with experiments by Lundquist and Svendsen (20) with rat liver homogenates, in which nearly all the ethanol metabolized was recovered as free acetate.

On the other hand, there seems to be little doubt that the liver can activate (and consequently oxidize) acetate, but at a much lower rate than the oxidation of ethanol to acetate. In peripheral tissues, however, acetate is readily metabolized, as is also evident in the present experiments.

For the interpretation of experiments in which hepatic venous blood is examined it must be kept in mind that a large part of the blood (the portal blood) has passed through other organs before reaching the liver. It seems reasonable to suppose that while the liver produces, almost exclusively, acetate from the available ethanol without further oxidation, the organs of the portal area may oxidize some of the acetate present in the arterial blood feeding these organs. In this case the measured acetate formation will be less than the ethanol consumption in the splanchnic area.

In Table VI the oxygen consumption calculated for these processes is compared with the measured oxygen consumption in the splanchnic area. On the average, 74 per cent of the oxygen consumption has been used in the oxidation of ethanol and acetate. It must be noted that the

$$
\text { TABLE V }
$$

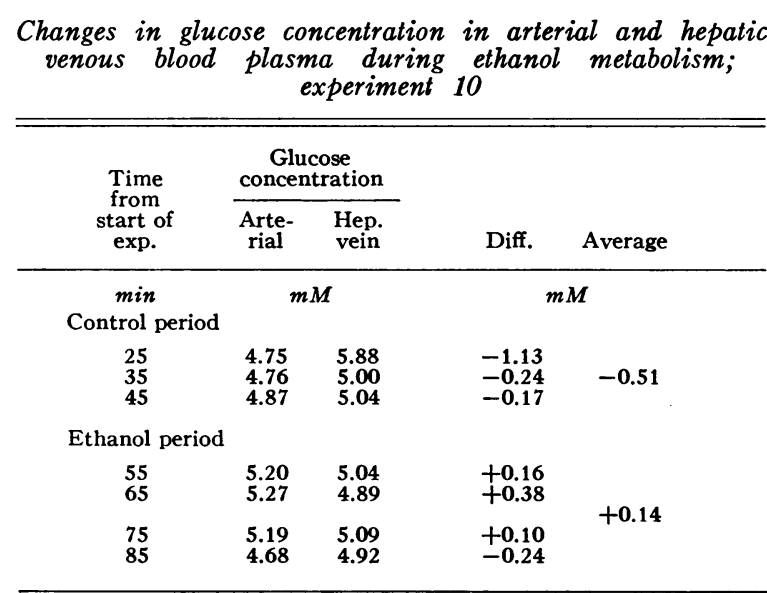


TABLE VI

Splanchnic oxygen consumption in relation to the metabolism of ethanol *

\begin{tabular}{|c|c|c|c|c|c|}
\hline \multirow{3}{*}{ Exp. no. } & \multicolumn{4}{|c|}{ Oxygen consumption required for oxidation: } & \multirow{3}{*}{$\begin{array}{r}\begin{array}{r}\text { Total calc. } \\
\mathrm{O}_{2} \text { consump. } \\
\text { as } \% \text { of } \\
\text { measured } \\
\mathrm{O}_{2} \text { consump. }\end{array} \\
\%\end{array}$} \\
\hline & \multicolumn{2}{|c|}{$\begin{array}{l}\text { Of ethanol to } \\
\text { acetate (liver) }\end{array}$} & \multicolumn{2}{|c|}{$\begin{array}{c}\text { Of acetate to } \\
\mathrm{CO}_{2}+\mathrm{H}_{2} \mathrm{O} \\
\text { (extrahep. spl. area) }\end{array}$} & \\
\hline & mmoles/min & $\% \dagger$ & mmoles/min & $\% \dagger$ & \\
\hline 1 & 2.14 & 48 & 1.86 & 41 & 89 \\
\hline 2 & 1.80 & 53 & 1.63 & 48 & 101 \\
\hline 3 & 1.78 & 41 & 0.62 & 14 & 55 \\
\hline 4 & 1.15 & 54 & 0 & 0 & 54 \\
\hline 5 & 2.29 & 63 & 1.52 & 42 & $105 \ddagger$ \\
\hline 6 & 1.33 & 34 & 0 & 0 & $34+$ \\
\hline 7 & 0.87 & 35 & 0.14 & 6 & 41 \\
\hline 8 & 1.24 & 59 & 0.22 & 11 & 70 \\
\hline 9 & 1.58 & 60 & 1.50 & 57 & $117 \S$ \\
\hline 10 & 1.31 & 43 & 1.04 & 34 & $77^{8}$ \\
\hline Average & 1.55 & 49 & 0.85 & 25 & 74 \\
\hline
\end{tabular}

* The figures are calculated on the assumption that all the ethanol not accounted for as acetate is completely oxidized to $\mathrm{CO}_{2}$ and water. Since the acetate oxidation may have taken place largely in the extrahepatic part of the splanchnic area, this has been listed separately.

+ Per cent of the measured oxygen consumption in the splanchnic area.

In this experiment the net increase in formation of ketone bodies of $0.26 \mathrm{mmole} / \mathrm{min}$ was taken into account.

$\S$ In this experiment the figures given for the acetate formation are minimal values. The actual values may have been considerably higher, the oxygen requirement for complete oxidation, therefore, correspondingly lower.

calculations of Table VI imply the assumption that about one-third of the acetate elimination in the body takes place in the extrahepatic splanchnic organs. The figures for the extrahepatic mesenteric oxygen uptake calculated to account for the acetate disappearance do not seem unreasonably high in any of the experiments. Tygstrup, Winkler, Mellemgaard and Andreassen (21) found that, on the average, 34 per cent of the splanchnic oxygen was consumed outside of the liver. The possibility that acetoacetate and $\beta$-hydroxybutyrate are formed in the liver from ethanol has been ruled out. An increase in ketone body formation during ethanol infusion was observed in only one experiment, and this was quantitatively unimportant.

A third acetate pathway which should be considered is the incorporation into other substances, notably lipids. Such processes undoubtedly do take place, and equally well from ethanol and acetate $(22,23)$, but to a very minor degree, which can at most explain a small fraction of the acetate deficit in some of the experiments (24), if results obtained in animals are accepted as valid in man. It is therefore considered most probable that all of the ethanol is oxidized to free acetate in the liver, and that the reason for the low recovery of acetate in the hepatic venous blood in some experiments is mainly oxidation in the extrahepatic splanchnic area.

Lactate analyses were made in order to decide whether some of the ethanol oxidation takes place as a dismutation reaction-i.e., coupled to the reduction of pyruvate to lactate. Such a process would mean that the liver could deal with a larger quantity of ethanol without complete oxidation of the hydrogen. The increase in blood lactate, however, was not caused exclusively by the liver but may indicate that the peripheral tissues prefer acetate rather than lactate as a fuel.

The finding that the ratio of acetoacetate to $\beta$-hydroxybutyrate decreases during ethanol metabolism to about half the control value in hepatic venous blood is another indication that the ratio $\mathrm{DPNH} / \mathrm{DPN}$ is increased in the liver during alcohol metabolism $(25,26)$. A similar observation was made by Büttner, Portwich and Engelhardt (27), who found that the ratio of pyruvate to lactate, which is also a DPN-dependent redox system, diminished in rats given ethanol. All these findings strongly suggest that the change in the state of oxidation of the coenzymes is a very important consequence of ethanol metabolism. It is indeed possible that this phenomenon is responsible for the radical changes in metabolism of the liver which must take place as soon as ethanol 
is present in the circulating blood. An example of this change is the decline of galactose utilization (17).

The magnitude of the ethanol consumption in the splanchnic area in these experiments may seem rather low, being $4.3 \mathrm{~g}$ per hour as compared with a generally accepted figure for the ethanol elimination of about $7 \mathrm{~g}$ per hour. The results are, however, in agreement with those of Larsen (28). In both cases the experimental subjects were fasted for at least 12 hours before the experiment. Fasting has been shown in animals $(29,30)$ to reduce the rate of ethanol combustion. It is not probable that the low rate is a consequence of the low concentration employed, since similar low combustion rates were recorded in experiments at higher ethanol concentration $(20 \mathrm{mM})(28)$. The observation that oxygen consumption does not change significantly when ethanol infusion is started, taken along with the finding that the ATP concentration of liver is not diminished by ethanol administration (27), sheds some light on the question of oxidative phosphorylation from extramitochondrial DPNH. The alcohol dehydrogenase responsible for the oxidation of ethanol is known to be exclusively present in the cytoplasm (31). It is therefore suggested that the yield of high energy bonds from DPNH is the same whether the DPNH is formed inside the mitochondria or not.

From Table VI it is calculated that, if 35 per cent of the total oxygen consumption in the splanchnic area takes place outside the liver (21), about 75 per cent of the oxygen consumption of the liver is used for ethanol metabolism. If the assumption made in Table VI that acetate is oxidized exclusively in the extrahepatic part of the splanchnic area is not justified, the figure will be even higher (up to 100 per cent).

This raises the question of what mechanism causes the "normal" metabolic processes to be suppressed, and also what consequences this change may have for the normal functions of the liver. As to the first question it is perhaps natural to regard the increased DPNH/DPN ratio as a possible clue, but this has not as yet been established.

Like Castenfors, Hultman and Josephson (32), we could not confirm Mendeloff's (33) observation that the hepatic blood flow was increased during ethanol metabolism. Castenfors and colleagues found a small reduction in flow, which they thought might be unrelated to the ethanol given. In our cases the fall in flow was statistically significant, while in seven control experiments, in which the hepatic blood flow was observed for a similar interval, there was no significant reduction in the period corresponding to the ethanol period of the present experiments. Since other circulatory parameters (e.g., the cardiac output) have not been examined, the cause of the reduction in the hepatic blood flow cannot be stated.

It must therefore be concluded that no reaction, either metabolic or vasomotor, takes place to compensate the large amount of oxygen required by the liver for the oxidation of ethanol.

\section{SUM MARY}

1. The disappearance of ethanol and the formation of acetate in the splanchnic area were measured in human subjects through analysis of arterial and hepatic venous blood. At the same time liver blood flow and splanchnic oxygen consumption were determined. A quantity of acetate corresponding to 50 to 100 per cent of the ethanol metabolized was found in blood from the hepatic veins. The arterial acetate concentration reached a constant level of about $0.8 \mathrm{mM}(50 \mu \mathrm{g}$ per $\mathrm{ml}$ ) shortly after the administration of ethanol.

2. The splanchnic oxygen consumption was not significantly changed by the infusion of ethanol, whereas the hepatic blood flow showed a small but significant decrease.

3. Formation of ketone bodies by the liver was not significantly changed when ethanol was given, but the ratio acetoacetate $/ \beta$-hydroxybutyrate decreased to about half the control value.

4. Lactate concentration in the arterial blood increased during ethanol infusion, but this was not exclusively caused by an increased output from the liver.

5. The significance of the findings in relation to the regulation of liver metabolism is discussed.

\section{REFERENCES}

1. Lundsgaard, E. Alcohol oxidation as a function of the liver. C. R. Lab. Carlsberg, Sér. chim. 1938, 22, 333.

2. Lundquist, F., Fugmann, U., Kläning, E., and Rasmussen, $H$. The metabolism of acetaldehyde in mammalian tissues; reactions in rat-liver sus- 
pensions under anaerobic conditions. Biochem. J. 1959, 72, 409.

3. Lundquist, F. The concentration of acetate in blood during alcohol metabolism in man. Acta physiol. scand. 1960, 175, 97.

4. Forsander, O. A., and Räihä, N. C. R. Metabolites produced in the liver during alcohol oxidation. J. biol. Chem. 1960, 235, 34.

5. Seligson, D., Waldstein, S. S., Giges, B., Meroney, W. H., and Sborov, V. M. Some metabolic effects of ethanol in humans. Clin. Res. Proc. 1953, 1, 86.

6. Winkler, K., Tygstrup, N., and Munkner, T. A study of Gaebler's method for determination of Bromsulfalein in plasma. Scand. J. clin. Lab. Invest. $1960,12,357$.

7. Lundquist, F. The determination of ethyl alcohol in blood and tissues in Methods of Biochemical Analysis, D. Glick, Ed. New York, Interscience, 1959, vol 7, p. 217.

8. Lundquist, F., Fugmann, U., and Rasmussen, H. A specific method for the determination of free acetate in blood and tissues. Biochem. J. 1961, 80, 393.

9. Hansen, O. A specific, sensitive and rapid micromethod for determination of ketone bodies in blood. Scand. J. clin. Lab. Invest. 1959, 11, 259.

10. Somogyi, M. Notes on sugar determination. J. biol. Chem. 1952, 195, 19.

11. Horn, H. D., and Bruns, F. H. Quantitative Bestimmung von $\mathrm{L}(+)$-Milchsäure mit Milchsäuredehydrogenase. Biochim. biophys. Acta 1956, 21, 378.

12. Bradley, S. E., Ingelfinger, F. J., Bradley, G. P., and Curry, J. J. The estimation of hepatic blood flow in man. J. clin. Invest. 1945, 24, 890.

13. Bartels, H. Potentiometrische Bestimmung des Sauerstoffdruckes im Vollblut mit der Quecksilbertropfelektrode. Pflüg. Arch. ges. Physiol. 1951, 254, 107.

14. Astrup, P. A simple electrometric technique for the determination of carbon dioxide tension in blood and plasma, total content of carbon dioxide in plasma, and bicarbonate content in "separated" plasma at a fixed carbon dioxide tension $(40 \mathrm{~mm}$ $\mathrm{Hg}$ ). Scand. J. clin. Lab. Invest. 1957, 8, 33.

15. Bondy, P. K. Spontaneous fluctuations in glucose content of the hepatic venous blood in resting normal human beings. J. clin. Invest. 1952, 31, 231.

16. Singer, R. B., and Hastings, A. B. An improved clinical method for the estimation of disturbances of the acid-base balance of human blood. Medicine (Baltimore) 1948, 27, 223.

17. Tygstrup, N., and Lundquist, F. The effect of ethanol on the galactose elimination in man. J. Lab. clin. Med. 1962, 59, 102.

18. Forsander, O., Räihä, N., and Suomalainen, H. Oxydation des Äethylalkohols in isolierter Leber und isoliertem Hinterkörper der Ratte. Hoppe-Seylers Z. physiol. Chem. 1960, 318, 1.
19. Bartlett, G. R., and Barnet, H. N. Some observations on alcohol metabolism with radioactive ethyl alcohol. Quart. J. Stud. Alcohol 1949, 10, 381.

20. Lundquist, F., and Svendsen, I. The metabolism of ethanol in rat liver suspensions. Submitted for publication.

21. Tygstrup, N., Winkler, K., Mellemgaard, K., and Andreassen, M. Determination of the hepatic arterial blood flow and oxygen supply in man by clamping the hepatic artery during surgery. J. clin. Invest. 1962, 41, 447.

22. Lieber, C. S., De Carli, L. M., and Schmid, R. Effect of ethanol on fatty acid metabolism in liver slices. Biochem. biophys. Res. Com. 1959, 1, 302.

23. Smith, M. E., and Newman, H. W. Ethanol-1-C ${ }^{14}$ and acetate-1- $\mathrm{C}^{14}$ incorporation into lipid fractions in the mouse. Proc. Soc. exp. Biol. (N. Y.) 1960, 104, 282.

24. Casier, H., and Polet, $H$. Influence du disulfiram (Antabus) sur le métabolisme de l'alcool éthylique marqué chez la souris. Arch. int. Pharmacodyn. 1958, 113, 439.

25. Smith, M. E., and Newman, H. W. The rate of ethanol metabolism in fed and fasting animals. J. biol. Chem. 1959, 234, 1544.

26. Forsander, O., Räihä, N., and Suomalainen, H. Alkoholoxydation und Bildung von Acetoacetat in normaler und glykogenarmer intakter Rattenleber. Hoppe-Seylers Z. physiol. Chem. 1958, 312, 243.

27. Büttner, H., Portwich, F., and Engelhardt, K. Der $\mathrm{DPN}^{+}$-und DPN-H-Gehalt der Rattenleber während des Abbaues von Äthanol und seine Beeinflussung durch Sulfonylharnstoff und Disulfiram. Naunyn-Schmiedeberg's Arch. exp. Path. Pharmak. 1961, 240, 573.

28. Larsen, J. A. The determination of the hepatic blood flow by means of ethanol. Scand. J. clin. Lab. Invest. 1959, 11, 340.

29. Le Breton, E. Signification physiologique de l'oxydation de l'alcool dans l'organisme. III. Recherches physiologiques concernant l'utilisation de l'éthanol par les êtres vivants. Ann. Physiol. Physicochim. biol. 1936, 12, 369.

30. Owens, A. H., Jr., and Marshall, E. K., Jr. The metabolism of ethyl alcohol in the rat. J. Pharmacol. exp. Ther. 1955, 115, 360.

31. Nyberg, A., Schuberth, J., and Änggård, L. On the intracellular distribution of catalase and alcohol dehydrogenase in horse, guinea pig and rat liver tissues. Acta chem. scand. 1953, 7, 1170.

32. Castenfors, H., Hultman, E., and Josephson, B. Effect of intravenous infusions of ethyl alcohol on estimated hepatic blood flow in man. J. clin. Invest. 1960, 39, 776.

33. Mendeloff, A. I. Effect of intravenous infusions of ethanol upon estimated hepatic blood flow in man. J. clin. Invest. 1954, 33, 1298. 